Canadian Journal of Fisheries and Aquatic Sciences, 1989, v.46, n.12, pp.2095-2103.

Online ISSN: 1205-7533

Print ISSN: 0706-652X

DOI:10.1139/f89-259

http://pubs.nrc-cnrc.gc.ca/rp-ps/journalDetail.jsp?jcode=cjfas\&lang=eng

http://article.pubs.nrc-

cnrc.gc.ca/RPAS/rpv?hm=HInit\&journal=cjfas\&volume=46\&calyLang=eng\&afpf=f89-259.pdf (C) 1989 NRC Canada 


\title{
Comparative Vulnerability of Three Esocids to Largemouth Bass (Micropterus salmoides) predation
}

\author{
David H. Wahl' and Roy A. Stein \\ Ohio Cooperative Fish and Wildlife Research Unit and Department of Zoology, The Ohio State University, 1735 Neil Avenue, Columbus, OH 43210 , \\ USA
}

Wahl, D. H., and R. A. Stein. 1989. Comparative vulnerability of three esocids to largemouth bass (Micropterus salmoides) predation. Can. J. Fish. Aquat. Sci. 46: 2095-2103.

We compared vulnerability among tiger muskellunge (Esox masquinongy $\times E$. lucius) (TM), northern pike $(E$. lucius) (NP), and muskellunge (E. masquinongy) (M) to predation by largemouth bass (Micropterus salmoides). Equal numbers (about 25/ha) and sizes (either 145, 180, or $205 \mathrm{~mm}$ ) of each esocid taxa were stocked into three reservoirs (40-89 ha) during 3 yr (five stockings total). Tiger muskellunge were significantly more susceptible to predation $(\bar{x}=30 \%$, range $1-53 \%$ mortality) than muskellunge $(\bar{x}=12 \%$, range $2-26 \%$; northern pike were intermediate in susceptibility $(\bar{x}=19 \%$, range $2-35 \%)$. Esocid size influenced predation rates for all taxa; losses to predation by largemouth bass decreased from an average of $31 \%$ at $145 \mathrm{~mm}$ to $2 \%$ at $205 \mathrm{~mm}$. Pond experiments $(N=7)$ provided results similar to reservoirs: $T M>N P>M$. In laboratory pools with simulated vegetation $(N=106$ experiments), susceptibility to predation among esocids did not differ. Dispersal rates by esocids were similar in reservoirs and all taxa preferred vegetated habitats. However, differential habitat selection may partially explain why tiger muskellunge are more vulnerable to largemouth bass predation, as they spent more time in open than vegetated habitats in both pond and pool experiments than either of the parent species. For all taxa, stocking lengths $\geqslant 205 \mathrm{~mm}$ in fall will increase survival by reducing predatory losses.

Nous avons comparé la sensibilité du Grand Brochet (Esox lucius) (NP), du Maskinongé (E. masquinongy) (M), et de la forme hybride de ces deux espèces (E. masquinongy $\times E$. lucius) à la prédation exercée par l'Achigan à grande bouche (Micropterus salmonides). Des représentants de même longueur $(145,180$, ou $205 \mathrm{~mm}$ ) de chaque taxon d'Ésocidae ont été maintenus en captivité en nombre égal, soit environ 25 par hectare, dans trois réservoirs d'une superficie de 40 à 89 ha pendant trois ans (cinq empoissonnements au total). La forme hybride était beaucoup plus sensible à la prédation ( $\bar{x}=30 \%$, mortalité de 1 à $53 \%$ ) que le Maskinongé $(\bar{x}=12 \%$, mortalité de 2 à $26 \%$ ), tandis que le Grand Brochet occupait une position intermédiaire ( $\bar{x}=19 \%$, mortalité de 2 à $35 \%$ ). Chez tous les taxons, la taille influait sur le taux de prédation : les pertes moyennes dues à la prédation par l'Achigan à grande bouche étaient de $31 \%$ chez les sujets de $145 \mathrm{~mm}$ de long et seulement de $2 \%$ chez ceux qui avaient $205 \mathrm{~mm}$ de long. Des expériences faites dans des étangs $(N=7)$ ont donné des résultats similaires, à savoir TM $>N P>M$. Dans des mares artificielles aménagées en laboratoire simulant la présence de végétation $(N=106$ expériences), la sensibilité à la prédation était également comparable. Le taux de dispersion des Ésocidae était similaire dans les réservoirs : tous les poissons préféraient les milieux peuplés de végétation. Toutefois, des différences dans le choix de l'habitat peuvent expliquer en partie pourquoi la forme hybride est plus sensible à la prédation exercée par l'Achigan à grande bouche, car celle-ci passait plus de temps dans les milieux ouverts que les représentants des deux autres taxons, que ce soit dans les réservoirs ou dans les mares artificielles. Chez tous les taxons, l'introduction d'individus d'une longueur égale ou supérieure à $205 \mathrm{~mm}$ en automne accroîtra le taux de survie par la réduction des pertes dues à la prédation.

Received July 26, 1988

Accepted August 1, 1989

(J9823)

$\mathrm{n}$ aquatic systems, predators can determine species diversity and abundance of prey (Hurlbert et al. 1972; Macan 1977; Peckarsky and Dodson 1980; Crowder and Cooper 1982; Morin 1984). From a fisheries management perspective, predators may influence the success of a variety of management practices, including species introductions. However, few studies have examined the importance of predation in determining survival of stocked sport fish.

${ }^{1}$ Present address: Center for Aquatic Ecology, Illinois Natural History Survey and Department of Ecology, Ethology, and Evolution, University of Illinois, 607 E. Peabody Drive, Champaign, IL 61820, USA.

${ }^{2}$ The unit is sponsored jointly by the United States and Fish Wildlife Service, the Ohio Department of Natural Resources, The Ohio State University, and the Wildlife Management Institute.
Reçu le 26 juillet 1988 Accepté le 1 août 1989
Predators influence survival of stocked esocids (Weithman and Anderson 1977; Johnson 1978). Predation by largemouth bass (Micropterus salmoides) can account for as much as $45 \%$ of the mortality of tiger muskellunge (Esox masquinongy $\times E$. lucius) stocked in reservoirs (Stein et al. 1981; Carline et al. 1986). However, only indirect evidence (Belusz 1978; Johnson 1982; Serns and Andrews 1986) supports the idea that predators control survival of stocked muskellunge ( $E$. masquinongy) whereas preliminary evidence (Headrick 1985) suggests that predators do not determine survival of northern pike (E. lucius). Although these data suggest the importance of resident predators in determining survival of these three taxa, methodological differences among studies make comparisons of vulnerability impossible. Only by simultaneously stocking similar sizes into the same reservoir can directly comparable data for tiger muskellunge, muskellunge, and northern pike be obtained. 
Esocids are often artifically propagated and differences in hatchery rearing conditions may contribute to behavioral differences among taxa making them more or less vulnerable to resident fish predators. Reared in intensive culture with less cannibalism than northern pike, tiger muskellunge more readily accept a dry diet than muskellunge (Graff 1978). As a result, tiger muskellunge are fed pellets in hatchery troughs whereas northern pike and muskellunge are generally grown to stockable sizes on minnows in hatchery ponds. These differences in rearing environment may affect esocid habitat selection and susceptibility to predation. Habitat use influences risk to predation in other taxa (Werner et al. 1983; Kotler 1984; Mittelbach 1984) and we hypothesized that tiger muskellunge may be more susceptible than its parents to predation. In this study, we compare risk to largemouth bass predation among muskellunge, northern pike, and tiger muskellunge in laboratory, pond, and field experiments. With these data, we quantify differential habitat selection among esocid taxa and evaluate its influence on relative susceptibility to predation.

\section{Materials and Methods}

\section{Field Experiments}

To compare susceptibility to largemouth bass predation among tiger muskellunge, muskellunge, and northern pike, we stocked equal numbers and sizes (either 145, 180,205 mm) of esocids into three Ohio reservoirs during $3 \mathrm{yr}$ (Table 1). All esocids were reared at Ohio Division of Wildlife fish hatcheries. Tiger muskellunge were reared in troughs and fed a dry pellet diet whereas muskellunge and northern pike were raised on fathead minnows (Pimephales promelas) in ponds. To control growth and match final sizes, muskellunge and northern pike were transferred to troughs for 1 mo before stocking. Esocids were counted and a sample $(N=100)$ measured and weighed the day before each stocking (Table 1). Fish were transported to the reservoirs in aerated tanks with $0.5 \%$ salt (see Mather and Wahl (1989) for details of transport conditions). To evaluate poststocking mortality, we held 30 of each taxon in floating cages $(2.6 \times 0.9 \times 0.9 \mathrm{~m})$ for $4 \mathrm{~d}$; low $(<6.6 \%)$ nonpredatory mortality occurs immediately after stocking (Mather and Wahl 1989).

To estimate losses of esocids to predation, we examined stomachs from largemouth bass captured by electroshocking equally spaced transects (seven in North Reservoir and five each in Madison and Kokosing reservoirs) along the entire perimeter of the reservoir on days $1,2,3,5$, and 7 poststocking and at weekly intervals thereafter for $60 \mathrm{~d}$ (range $=30-113$ largemouth bass examined per sample date). Largemouth bass were measured (nearest $1 \mathrm{~mm}$ ), weighed (nearest $1 \mathrm{~g}$ ), fin- clipped, stomach contents recovered by pulsed gastric lavage (Foster 1977), and released. In the laboratory, prey obtained from largemouth bass stomachs were identified; northern pike and muskellunge were differentiated by vertebral structure (Crossman and Casselman 1969). Esocids from our stockings could not be confused with resident young-of-year fish, as no natural reproduction occurs in any of the three reservoirs. Tiger muskellunge, which have vertebrae similar to northern pike, were marked before stocking with oxytetracycline (Wahl and Stein 1987). Vertebrae of esocids recovered from largemouth bass stomachs were examined under ultraviolet light and tiger muskellunge identified by the presence of a yellow-gold flourophor. Esocids recovered from largemouth bass stomachs were measured as total, standard, or backbone length depending on stage of digestion (nearest $1.0 \mathrm{~mm}$ ). Total length of each esocid was estimated by regression equations between total lengths and either standard or backbone lengths $(N=50$ individuals/taxon) (see Fig. 1).

Abundance of largemouth bass was estimated using Schnabel mark-recapture procedures (Ricker 1975). Total densities of $1+$ and older largemouth bass were similar among the three reservoirs (range $=31-39 / \mathrm{ha}$ ). Size frequency distributions of largemouth bass also were similar among reservoirs and years (Kolmogorov-Smirnov test, $p>0.05$ ), except for Kokosing Reservoir which had higher numbers of 200- to $235-\mathrm{mm}$ fish. Even though density and size distribution of largemouth bass were similar among reservoirs, the proportion of largemouth bass capable of consuming esocids varied with the sizes stocked. As a result, the functional density of largemouth bass was lower for stockings of large as compared with small esocids. To avoid overestimating losses of esocids to predation, we included only largemouth bass capable of ingesting esocids in our density estimates (see Table 2). Minimum lengths of largemouth bass included in each population estimate were determined by dividing the length of the smallest stocked esocid by the largest prey/predator length ratio computed from lengths of esocids recovered from largemouth bass stomachs (as per Carline et al. 1986). No differences in prey/predator length frequencies occurred among esocid taxa (Fig. 1); regressions of cumulative frequency against prey/predator length were similar (ANCOVA, homogenity of slope, $p>0.14$ ). As a result, we used the largest prey/predator length ratio $(0.75)$ computed from combined data to determine the minimum length of largemouth bass to include in each population estimate; minimum lengths varied among reservoirs depending upon esocid stocking size (Table 2). Estimates of mortality by predation $(Y)$ for each taxon $(i)$ were determined as

$$
Y_{i}=\sum_{j=1}^{d} a_{j} / b_{j} \cdot x
$$

where $a=$ the number of each esocid taxa recovered from

TABLE 1. Summary of field conditions associated with experiments comparing susceptability to largemouth bass predation among tiger muskellunge (TM), northern pike (NP), and muskellunge (M). Length (nearest $1.0 \mathrm{~mm}$ ) and weight (nearest $0.1 \mathrm{~g}$ ) for each taxon were based on a sample $(N=100)$ measured the day before stocking.

\begin{tabular}{|c|c|c|c|c|c|c|c|c|c|}
\hline Reservoir (ha) & $\begin{array}{l}\text { Stocking } \\
\text { date }\end{array}$ & $\begin{array}{l}\text { No. of } \\
\text { each } \\
\text { taxon }\end{array}$ & No./ha & \multicolumn{3}{|c|}{ Total length $(95 \%$ C.I.) } & \multicolumn{3}{|c|}{ Wet weight (95\% C.I.) } \\
\hline North (89) 2 & 29 Aug. 1983 & 1150 & 13 & $183( \pm 3.0)$ & - & $180( \pm 3.9)$ & $29.0( \pm 1.6)$ & - & $24.6( \pm 1.9)$ \\
\hline North & 4 Sept. 1984 & 3000 & 34 & $177( \pm 2.2)$ & $179( \pm 3.5)$ & $179( \pm 4.2)$ & $24.4( \pm 1.1)$ & $30.7( \pm 1.9)$ & $23.9( \pm 1.9)$ \\
\hline Madison (40) 2 & 29 July 1985 & 1000 & 25 & $147( \pm 2.8)$ & $143( \pm 1.7)$ & $144( \pm 3.0)$ & $13.9( \pm 1.0)$ & $14.7( \pm 0.8)$ & $11.8( \pm 1.0)$ \\
\hline North 2 & 26 Aug. 1985 & 2150 & 24 & $208( \pm 4.5)$ & $205( \pm 4.7)$ & $205( \pm 3.9)$ & $44.3( \pm 2.7)$ & $44.6( \pm 3.6)$ & $39.4( \pm 2.6)$ \\
\hline
\end{tabular}




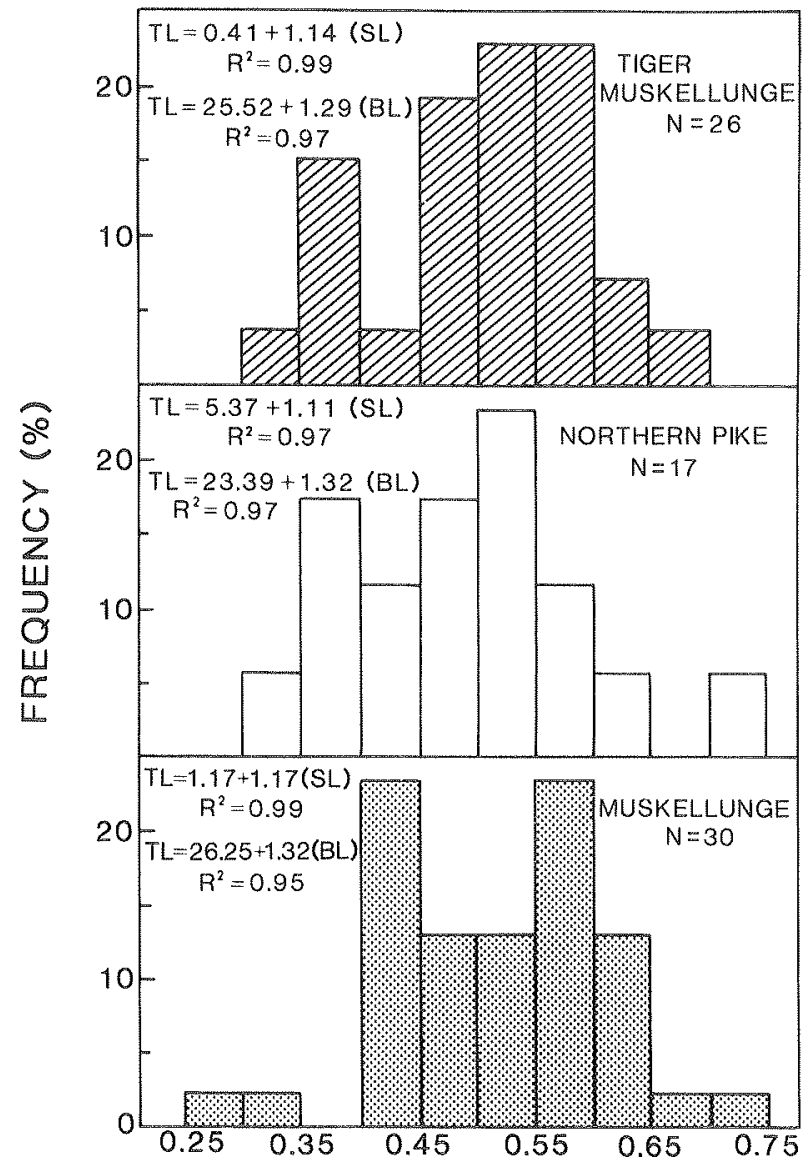

\section{ESOCID LENGTH (TL)/LARGEMOUTH BASS LENGTH (TL)}

FIG. 1. Frequency distribution of the total length of each of the three esocids recovered from stomachs divided by the total length of the largemouth bass that consumed them. Regression equations, used to estimate total length (TL) from partially digested standard lengths (SL) and backbone lengths (BL), are presented for each esocid taxon.

largemouth bass stomachs during a sample $(j), b=$ number of bass stomachs examined during a sample, $x=$ number of largemouth bass, and $d=$ number of days following stocking (60 in our experiments). Values between sampling dates were estimated by linear extrapolation. These relative estimates of esocid losses to predation assume largemouth bass stomach contents represent $1 \mathrm{~d}$ of feeding. At water temperatures encountered during our study $\left(20-22^{\circ} \mathrm{C}\right)$, evacuation rates of
21-26 h appear reasonable for largemouth bass (Beamish 1972; Hunt 1960), supporting our assumption.

To explain differential susceptibility to predation among esocids, habitat selection and taxon-specific dispersal patterns following stocking were quantified in North Reservoir. Of the seven equal length transects into which we divided North Reservoir, the two farthest from the single stocking site contained dense stands (75\% of shoreline) of lily pads (Nymphaea spp.) whereas the other transects were without vegetation. The proportion of esocids captured in these two transects allowed us to assess both differential habitat selection and dispersal rates.

\section{Pond Experiments}

Relative vulnerability of the three esocids to largemouth bass predation also was estimated in pond experiments conducted during $3 \mathrm{yr}(N=7$ experiments). Ponds were uniform in size ( $0.05 \mathrm{ha}, 1.5 \mathrm{~m}$ deep) and were clay bottomed; at pond edges, terrestrial vegetation (grasses) extended $1 \mathrm{~m}$ from the perimeter. Experimental design differed among years. In 1983, we stocked each of three ponds with 10 largemouth bass $(250-300 \mathrm{~mm})$ collected from Ohio reservoirs. One week after largemouth bass were stocked, we added 90 individuals of tiger muskellunge or muskellunge or northern pike of similar size to each pond. In 1984 and 1985, we divided each of six ponds into two equal sections with netting. Six largemouth bass, collected either from reservoirs (1984) or hatchery ponds (1985), were assigned randomly to one half of each pond. Both halves were stocked with 50 individuals of a single esocid taxon, each marked uniquely by the removal of a left or right pelvic fin. After $9 \mathrm{~d}$, ponds were drained to recover remaining esocids. To directly estimate losses of esocids to predation, we seined largemouth bass three or four times during each experiment and pumped their stomachs.

Habitat selection by the three esocids was assessed by snorkel observations. Three transects, two along the pond edge and one through the center, were swum on days when ponds were seined. Habitat (open or vegetated, upper or lower half of water column) was quantified for all esocids sighted.

\section{Laboratory Experiments}

To evaluate the effect of vegetation on susceptibility to predation among the three esocids, we conducted 106 experiments in circular pools ( $2.5 \mathrm{~m}$ in diameter, $0.5 \mathrm{~m}$ deep) at water temperatures of $18-23^{\circ} \mathrm{C}$ and a photoperiod of $14 \mathrm{~h}$ light : $10 \mathrm{~h}$ dark. Half the pool contained simulated aquatic vegetation $(250$ stems $\left./ \mathrm{m}^{2}\right)$ made from polypropylene line $(0.5 \mathrm{~m}$ long, $4 \mathrm{~mm}$

TABLE 2. Schnabel population estimates of largemouth bass in North, Kokosing, and Madison reservoirs determined following esocid stockings. Lengths of largemouth bass included in population estimates were based on the minimum size capable of ingesting the smallest esocid stocked. The $95 \%$ confidence intervals were calculated from fiducial limits for the binomial distribution (Ricker 1975).

\begin{tabular}{lcrrrr}
\hline \hline \multirow{2}{*}{$\begin{array}{c}\text { Reservoir } \\
\text { (year) }\end{array}$} & $\begin{array}{c}\text { Minimum total } \\
\text { length (mm) } \\
\text { marked }\end{array}$ & $\begin{array}{c}\text { Point } \\
\text { estimate }\end{array}$ & $95 \%$ C.I. & No./ha & $\%$ marked \\
\hline North (1983) & 210 & 1134 & $991-1324$ & 13 & 47 \\
Kokosing (1984) & 170 & 1758 & $1349-2520$ & 38 & 20 \\
North (1984) & 200 & 1860 & $1645-2138$ & 21 & 23 \\
Madison (1985) & 170 & 930 & $821-1072$ & 23 & 52 \\
North (1985) & 235 & 1030 & $782-1509$ & 12 & 25 \\
\hline
\end{tabular}


in diameter) whereas the other half contained no "vegetation." Line sections were fastened to wire mesh, covered with gravel, and extended to the water surface. These simulated vegetation densities are within the range of values observed for natural systems (Savino and Stein 1982).

Groups of six naive, similar-sized esocids $(140-210 \mathrm{~mm}, 50$ $60 \%$ of largemouth bass length), two of each species, were added to the pool $24 \mathrm{~h}$ before an experiment. Preliminary experiments $(N=15 /$ taxon $)$, with two individuals of a single taxon, indicated that habitat selection ( $N=4$ tank locations) among the three esocids was not influenced by the presence of the other taxon (MANOVA, $p>0.15$ ). Esocid location (upper or lower $0.25 \mathrm{~m}$ of water column) and habitat selection (open or vegetated portion of pool) were recorded for $1 \mathrm{~h}$ before and after introduction of the largemouth bass. Esocid habitat selection was recorded every $2 \min (N=30$ observations/experiment); mean values for each experiment were compared among esocid taxa. Largemouth bass $(250-350 \mathrm{~mm})$ starved for $24 \mathrm{~h}$ were released into the pool from a holding compartment. We used 15 largemouth bass; each individual was used in five to nine experiments. We attempted to evaluate largemouth bass behavior while capturing esocids, but capture rates of prey were extremely low (about one esocid per day). Following release of the largemouth bass, we quantified flight distances for each esocid and recorded habitat selection and initial distance from the largemouth bass for esocids followed. From these data, we compared behavior of esocids followed with those not followed by the largemouth bass. After $24 \mathrm{~h}$ we counted remaining esocids.

\section{Results}

\section{Field Experiments}

We recovered esocids from largemouth bass stomachs following each reservoir experiment (Table 3). All consumption of esocids by largemouth bass occurred within $30 \mathrm{~d}$ following stocking; most losses occurred during the first $7 \mathrm{~d}$. Based on estimates of the number of largemouth bass capable of ingesting esocids (Table 2) and daily estimates of the number of each esocid taxon eaten by this predator, we estimated that substantial numbers (range $=2-53 \%$ ) of all three esocid taxa stocked were eaten by largemouth bass (Table 3$)$. Tiger muskellunge $(\bar{x}=$ $30 \%$, range $1-53 \%$ ) were more vulnerable to predation than muskellunge $(\tilde{x}=12 \%, 2-26 \%$ ) (ANOVA, $p<0.05$, Tukey's multiple comparisons, $p=0.05)$ whereas northern pike $(\bar{x}=$
$19 \%, 2-35 \%$ ) were intermediate (Fig. 2). Losses of esocids to predation were negatively related to size for tiger muskellunge (Pearson correlation, $r=-0.92, p=0.03$ ) and northern pike $(r=-0.95, p=0.03)$, but not for muskellunge $(r=-0.44$, $p=0.46$ ). For all three taxa, predatory losses were least for the largest size class stocked $(205 \mathrm{~mm})$.

Abundance of alternate prey for largemouth bass could influence predation intensity on esocids. Because traditional sampling gears underestimate the abundance of gizzard shad, the primary forage in these systems, we used the proportion of largemouth bass with empty stomachs as an indirect measure of prey availability (as per Carline et al. 1986). We found no relationship between predatory mortality and percentage of largemouth bass with empty stomachs (range $45-55 \%$ ) (Pearson correlation, $r=-0.49, p=0.07$ ). In addition, losses from predation were not a function of largemouth bass density for either muskellunge (Pearson correlation, $r=0.68, p=$ 0.32 ) or northern pike $(r=-0.10, p=0.87)$, but were marginally related to largemouth bass density for tiger muskellunge $(r=0.88, p=0.05)$.

Habitat selection and dispersal rates were similar among the three esocids in North Reservoir. Within $30 \mathrm{~d}$ following each of three stockings, $>50 \%$ of all esocids (the exception being $36 \%$ of tiger muskellunge in 1983) were captured in the two vegetated transects farthest from the stocking site (Fig. 3). Because the majority of esocids occurred here, an area that occupied only $28 \%$ of the reservoir, all three esocids preferred vegetated habitats. Dispersal rates within each of the three stockings did not differ among esocids (Fig. 3, ANCOVA, homogeneity of slope, $p>0.23$ ).

\section{Pond Experiments}

To compare data collected from ponds for all $3 \mathrm{yr}$, we estimated control mortality for 1983 experiments using mean mortality in controls from other years $(\tilde{x}=16 \%, 95 \%$ confidence interval $= \pm 1.3$ ). Because mortalities were expressed as percentages, we used arcsin transformations to stabilize the variance (Steel and Torrie 1980). Experiments were blocked ( $N=$ 4) to account for effects of esocid size and year. Differences in mortalities between treatment (largemouth bass present) and control (no largemouth bass) were used to assess losses of esocids to predation. Tiger muskellunge were more susceptible to largemouth bass predation than muskellunge (two-way ANOVA, $p=0.04$, Tukey's multiple comparisons, $p=0.08$ ); although not different from either tiger muskellunge or muskel-

TABLE 3. Number of tiger muskellunge (TM), northern pike (NP), and muskellunge (M) recovered from largemouth bass stomachs following stocking in each reservoir. Estimates of predatory mortality were obtained on each sampling date by multiplying the number of each esocid per bass stomach by the number of largemouth bass in the population (see Table 2). Interpolating between sample dates and summing these daily values provided an estimate of the total number of esocids eaten. Northern pike were not stocked in North Reservoir in 1983.

\begin{tabular}{|c|c|c|c|c|c|c|c|}
\hline \multirow{2}{*}{$\begin{array}{l}\text { Reservoir } \\
\text { (year) }\end{array}$} & \multirow{2}{*}{$\begin{array}{c}\text { No. of } \\
\text { largemouth } \\
\text { bass examined }\end{array}$} & \multicolumn{3}{|c|}{$\begin{array}{l}\text { No. of esocids recovered } \\
\text { from bass stomachs }\end{array}$} & \multicolumn{3}{|c|}{$\begin{array}{l}\text { Estimated no. of } \\
\text { esocids eaten }\end{array}$} \\
\hline & & TM & NP & $\mathrm{M}$ & TM & NP & M \\
\hline North (1983) & 662 & 18 & - & 11 & 270 & - & 298 \\
\hline Kokosing (1984) & 425 & 14 & 11 & 4 & 610 & 308 & 98 \\
\hline North (1984) & 524 & 8 & 5 & 3 & 945 & 278 & 61 \\
\hline Madison (1984) & 758 & 29 & 23 & 19 & 402 & 349 & 234 \\
\hline North (1985) & 283 & 1 & 1 & 1 & 23 & 37 & 37 \\
\hline
\end{tabular}




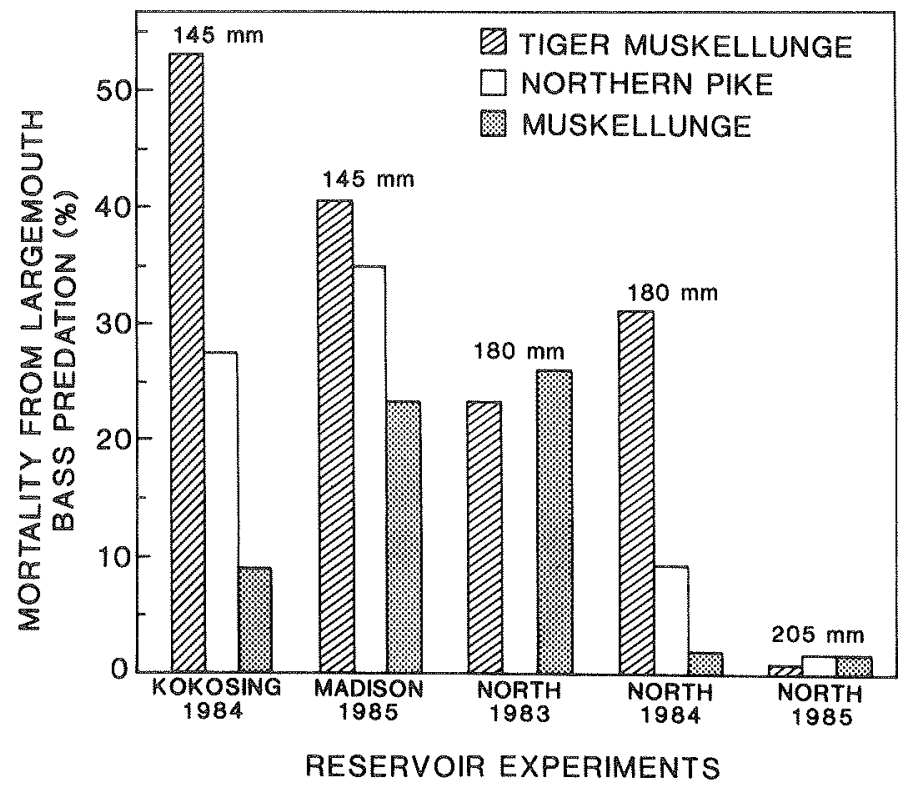

FIG. 2. Mortality for each esocid taxon attributable to largemouth bass predation following five reservoir experiments. Mean total lengths of esocids are given for each stocking. Northern pike were not stocked in North Reservoir in 1983.

lunge, northern pike were intermediate in susceptibility to predation. We found no consistent relationship between mortality and size either within or among esocid taxa. These patterns were strongly influenced by the use of largemouth bass with different levels of acclimation to ponds. Largemouth bass collected from hatchery ponds in 1985 were better acclimated to ponds than the reservoir largemouth bass used in the previous 2 yr. Before esocid introductions, $100 \%$ of largemouth bass examined contained food ( $\bar{x}=5.7 \mathrm{~g}$ food/bass) in 1985 as compared with $64 \%(\bar{x}=1.4 \mathrm{~g} /$ bass $)$ in the other $2 \mathrm{yr}$. As a result, predation rates by these acclimated bass were higher. Comparing only experiments with similarly acclimated largemouth bass, larger esocids suffered lower predatory mortality (two-way ANOVA, $p<0.04$, Tukey's multiple comparisons, $p<0.05)$. We also assessed losses of esocids to predation in pond experiments by directly pumping largemouth bass stomachs. In general, the number of esocids per largemouth bass stomach peaked on the first day following stocking and gradually declined over $9 \mathrm{~d}$ (Fig. 4). As in reservoir experiments, we used the number of esocids recovered from largemouth bass stomachs to obtain daily estimates of losses to predation for each esocid (Table 4). Again, tiger muskellunge were more susceptible to largemouth bass predation than muskellunge (ANOVA, $p=0.01$, Tukey's multiple comparisons, $p=0.02$ ); northern pike were intermediate in susceptibility to predation. Estimates of largemouth bass predation, determined by differences in mortality between treatment and control and by examination of largemouth bass stomach contents, were similar for five of the seven replicates (Table 4). Discrepancies between the two methods of estimating losses to predation occurred in the first two replicates of 1985 , where substantially lower estimates of muskellunge mortality resulted from examination of largemouth bass stomachs compared with the number of fish remaining at the end of the experiment. During snorkel transects, we found four and five dead muskellunge, respectively, in the largemouth bass half of each of these two experiments. Deleting these two experiments, results were similar between

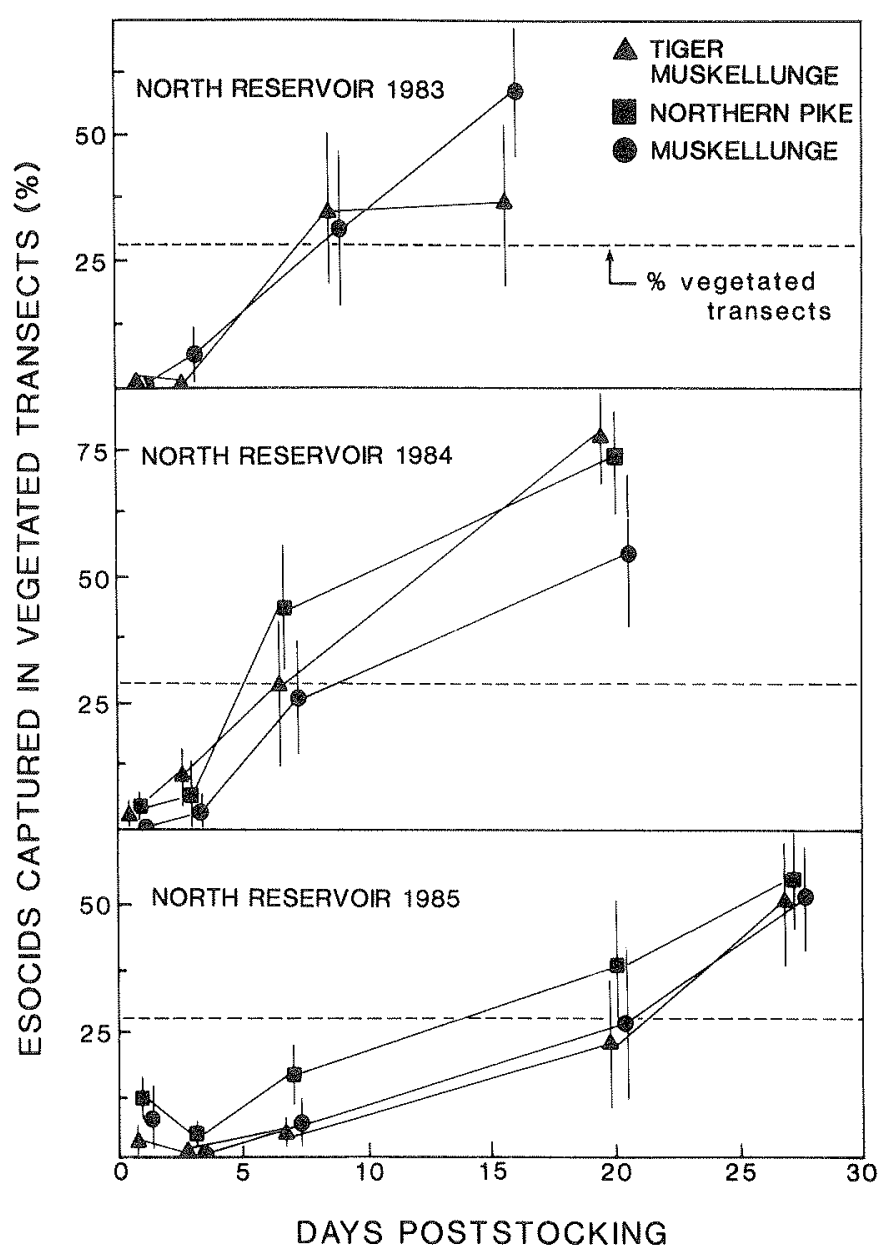

FIG. 3. Percent of each esocid taxon captured in the two vegetated transects $(N=7$ total transects) following three stockings in North Reservoir. Vertical lines represent $95 \%$ confidence intervals. Movement rates among taxa into these two transects (located farthest from the stocking site) did not differ in any year (ANCOVA, homogeneity of slope, $p>0.23$ ).

TABLE 4. Mortality among tiger muskellunge (TM), northern pike (NP), and muskellunge (M) attributable to largemouth bass predation after $9 \mathrm{~d}$ in 0.05 -ha ponds. Mortality estimates were derived by difference in mortality between treatment (bass present) and control (no bass) pond halves and by directly pumping largemouth bass stomachs. Experiments in 1983 consisted of treatment-only ponds; control mortality was estimated using mean mortality in controls from other years. Esocid total lengths $(\mathrm{mm})$ represent all fish used in experimental replicates $(N=100 /$ taxon $)$.

\begin{tabular}{|c|c|c|c|c|c|c|c|}
\hline \multirow[b]{2}{*}{ Year } & \multirow{2}{*}{$\begin{array}{c}\text { Esocid total } \\
\text { length }(\mathrm{mm}) \\
(95 \% \text { C.I.) }\end{array}$} & \multicolumn{3}{|c|}{$\begin{array}{l}\text { Treatment minus } \\
\text { control mortality (\%) }\end{array}$} & \multicolumn{3}{|c|}{$\begin{array}{l}\text { Recovered from bass } \\
\text { stomachs }(\%)\end{array}$} \\
\hline & & TM & NP & M & TM & NP & $\mathrm{M}$ \\
\hline 1983 & $136( \pm 0.9)$ & 47 & 29 & 7 & 43 & 25 & 0 \\
\hline 1984 & $\begin{array}{l}169( \pm 0.9) \\
170( \pm 0.9)\end{array}$ & $\begin{array}{l}38 \\
22\end{array}$ & $\begin{array}{l}18 \\
10\end{array}$ & $\begin{array}{l}0 \\
4\end{array}$ & $\begin{array}{l}23 \\
17\end{array}$ & $\begin{array}{r}16 \\
4\end{array}$ & $\begin{array}{l}0 \\
4\end{array}$ \\
\hline 1985 & $\begin{array}{l}172( \pm 0.8) \\
172( \pm 0.9) \\
202( \pm 0.7) \\
201( \pm 0.7)\end{array}$ & $\begin{array}{l}54 \\
38 \\
38 \\
36\end{array}$ & $\begin{array}{l}58 \\
48 \\
32 \\
30\end{array}$ & $\begin{array}{l}78 \\
66 \\
12 \\
42\end{array}$ & $\begin{array}{l}65 \\
26 \\
49 \\
46\end{array}$ & $\begin{array}{l}34 \\
40 \\
48 \\
18\end{array}$ & $\begin{array}{l}44 \\
19 \\
16 \\
39\end{array}$ \\
\hline
\end{tabular}




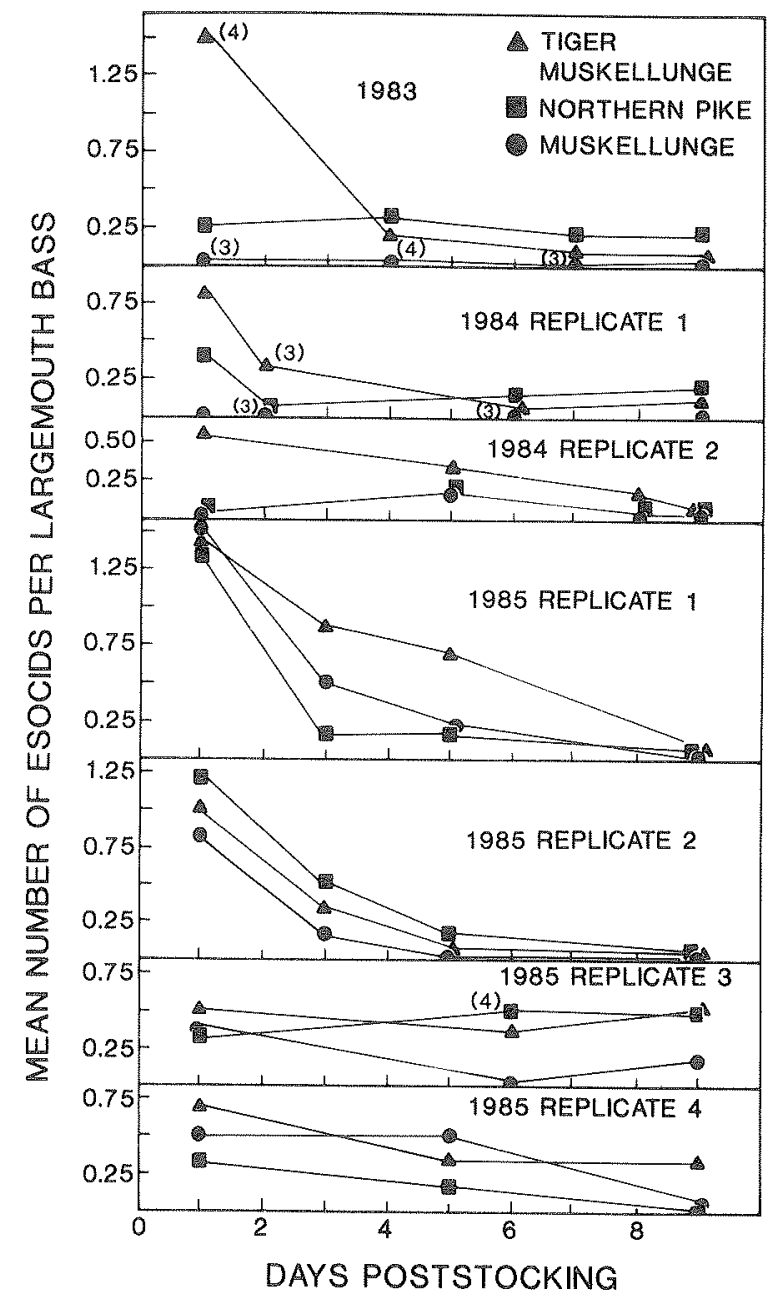

FIG. 4. Mean number of esocids recovered from largemouth bass stomachs following stocking in seven replicate pond experiments completed during 3 yr. Numbers of largemouth bass (3-10), collected by seining, are given in parentheses only when sample sizes were $<5$.

the two methods of estimating losses to largemouth bass predation.

We examined habitat selection by esocids by swimming transects. Without exception, esocids resided near the perimeter of the pond (about $0.5 \mathrm{~m}$ deep). Tiger muskellunge $(N=95$ observations) spent more time in the open than either northern pike $(N=27)$ or muskellunge $(N=58)$ (Fig. 5 , chi-square, partitioned degrees of freedom, $p<0.005)$. In contrast, northern pike were most often associated with the bottom of the pond whereas tiger muskellunge and muskellunge spent the majority of their time in the upper portion of the water column (Fig. 5, chi-square, $p<0.005$ ).

\section{Laboratory Experiments}

In the laboratory, we assessed habitat selection and location in the water column for comparison with field results. All esocids spent the majority of their time in the vegetated portion of the pool; tiger muskellunge spent more time in the open than either muskellunge or northern pike (Fig. 5, ANOVA, Tukey's multiple comparisons, $p=0.0001$ ). As in pond experiments, northern pike were more often associated with the substrate than either muskellunge or tiger muskellunge (Fig. 5, ANOVA, Tukey's multiple comparisons, $p=0.001$ ).

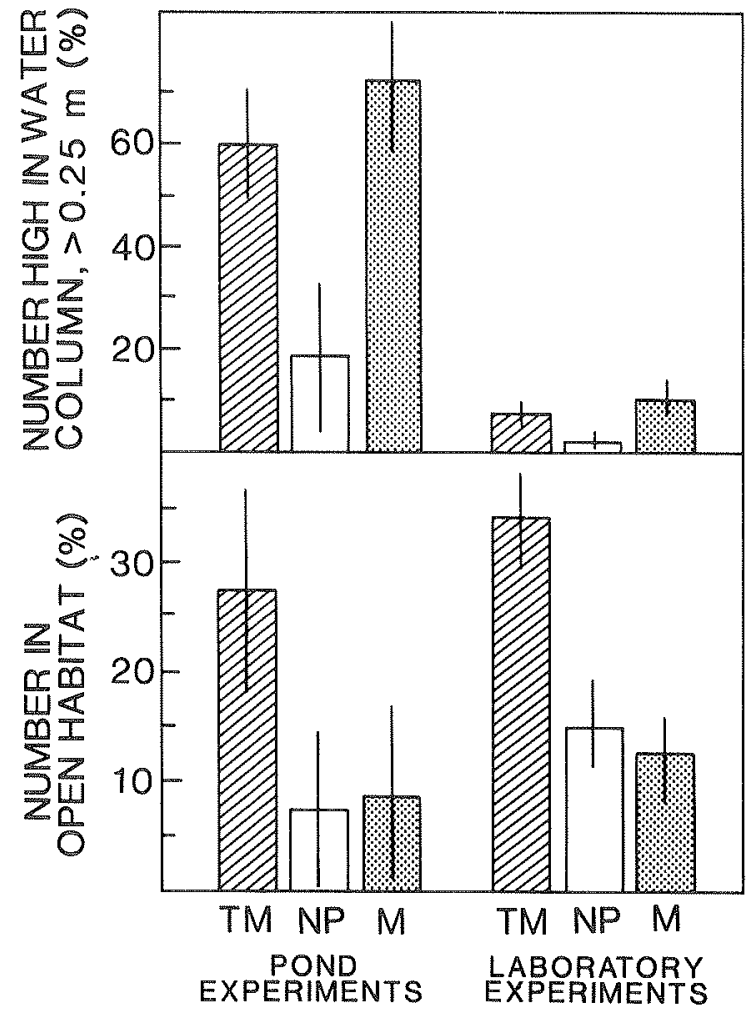

FIG. 5. Habitat selection (open or vegetated) and location in the water column (upper $0.25 \mathrm{~m}$ or lower $0.25 \mathrm{~m}$ ) for each esocid taxon during pond and laboratory experiments. Values for pond experiments represent percent of total number of observations per taxa during snorkel transects. Observations for laboratory experiments $(N=106$ replicates) were recorded at 2 -min intervals during $1 \mathrm{~h}$ before largemouth bass release. Vertical lines represent $95 \%$ confidence intervals.

After largemouth bass release, we quantified esocid response to largemouth bass. Esocid movement increased following largemouth bass release $(t$-test, $p<0.001)$; number of position changes increased more ( $156 \%$ increase) for northern pike than for either muskellunge $(62 \%)$ or tiger muskellunge $(31 \%)$ (ANOVA, Tukey's multiple comparisons, $p<0.05$ ). No difference in distances maintained from largemouth bass occurred either among taxa within a habitat (Table 5, ANOVA, $p<$ $0.32)$ or between open and vegetated habitats $(t$-test, $p<0.13)$. However, flight distances were greater in open than in vegetated habitats for all esocids ( $t$-test, $p<0.02)$ and were greater for northern pike than for the other taxa within a habitat (Table 5 , ANOVA, $p<0.001)$. We also recorded the number of times each esocid failed to flee as a largemouth bass approached within $30 \mathrm{~cm}$. Tiger muskellunge remained motionless more often $(48 \%)$ than either muskellunge $(23 \%)$ or northern pike (14\%) (chi-square, partitioned degrees of freedom, $p<0.005$ ).

Largemouth bass followed all three esocids more often in open than in vegetated habitats (Table $5, t$-test, $p<0.05$ ); however, we observed no difference among taxa within a habitat (ANOVA, $p=0.44$ ). Largemouth bass followed tiger muskellunge greater distances in open than in vegetated habitats (Table $5, t$-test, $p<0.02$ ), but followed the other taxa equal distances $(t$-test, $p<0.37)$. Within a habitat, largemouth bass followed northern pike for greater distances than the other two taxa when they were in the vegetation (ANOVA, $p=0.03$ ), but not in the open (ANOVA, $p=0.15$ ). After $24 \mathrm{~h}$, all esocids were equally susceptible to largemouth bass predation in laboratory pools (Fig. 6 , chi-square, $p=0.15$ ). Comparison of 
TABLE 5. Comparison of esocid behaviors (recorded at 2-min intervals) in open and vegetated habitats during 1-h experiments $(N=106)$ following release of largemouth bass into pools. Mean flight distance was based on a subset of 30 experiments whereas bass behavior (distance and number of follows) represents means for individual bass $(N=15)$. Number in parentheses represent $95 \%$ confidence intervals. Row values followed by the same letter do not differ (ANOVA, Tukey's multiple comparisons, $p$ $<0.05$ ).

\begin{tabular}{|c|c|c|c|c|}
\hline \multirow[b]{2}{*}{$\begin{array}{c}\text { Esocid/bass } \\
\text { behavior }\end{array}$} & \multirow[b]{2}{*}{$\begin{array}{l}\text { No. of } \\
\text { replicates }\end{array}$} & \multicolumn{3}{|c|}{ Esocid taxa } \\
\hline & & $\begin{array}{c}\text { Tiger } \\
\text { muskellunge }\end{array}$ & $\begin{array}{l}\text { Northern } \\
\text { pike }\end{array}$ & Muskellunge \\
\hline $\begin{array}{l}\text { Distance to bass }(\mathrm{cm}) \\
\text { Open } \\
\text { Vegetated }\end{array}$ & 106 & $\begin{array}{l}56.2( \pm 7.5) a \\
62.9( \pm 5.2) a\end{array}$ & $\begin{array}{l}60.5( \pm 8.6) \mathrm{a} \\
67.3( \pm 5.3) \mathrm{a}\end{array}$ & $\begin{array}{l}49.4( \pm 9.2) a \\
62.3( \pm 5.8) a\end{array}$ \\
\hline $\begin{array}{l}\text { Flight distance }(\mathrm{cm}) \\
\text { Open } \\
\text { Vegetated }\end{array}$ & 30 & $\begin{array}{l}29.1( \pm 6.7) \mathrm{a} \\
18.7( \pm 3.3) \mathrm{a}\end{array}$ & $\begin{array}{l}47.0( \pm 6.7) b \\
29.9( \pm 4.6) b\end{array}$ & $\begin{array}{l}27.1( \pm 6.3) \mathrm{a} \\
16.6( \pm 3.3) \mathrm{a}\end{array}$ \\
\hline $\begin{array}{l}\text { Mean number of follows } \\
\text { Open } \\
\text { Vegetated }\end{array}$ & 15 & $\begin{array}{l}1.8( \pm 0.2) \mathrm{a} \\
1.4( \pm 0.2) \mathrm{a}\end{array}$ & $\begin{array}{l}1.7( \pm 0.1) a \\
1.4( \pm 0.2) a\end{array}$ & $\begin{array}{l}1.5( \pm 0.2) \mathrm{a} \\
1.2( \pm 0.1) \mathrm{a}\end{array}$ \\
\hline $\begin{array}{l}\text { Distance followed }(\mathrm{cm}) \\
\text { Open } \\
\text { Vegetated }\end{array}$ & 15 & $\begin{array}{l}83.6( \pm 22.5) \mathrm{a} \\
40.8( \pm 19.9) \mathrm{a}\end{array}$ & $\begin{array}{l}70.5( \pm 23.9) b \\
87.2( \pm 23.3) b\end{array}$ & $\begin{array}{l}50.1( \pm 21.1) \mathrm{a} \\
37.9( \pm 21.1) \mathrm{a}\end{array}$ \\
\hline
\end{tabular}

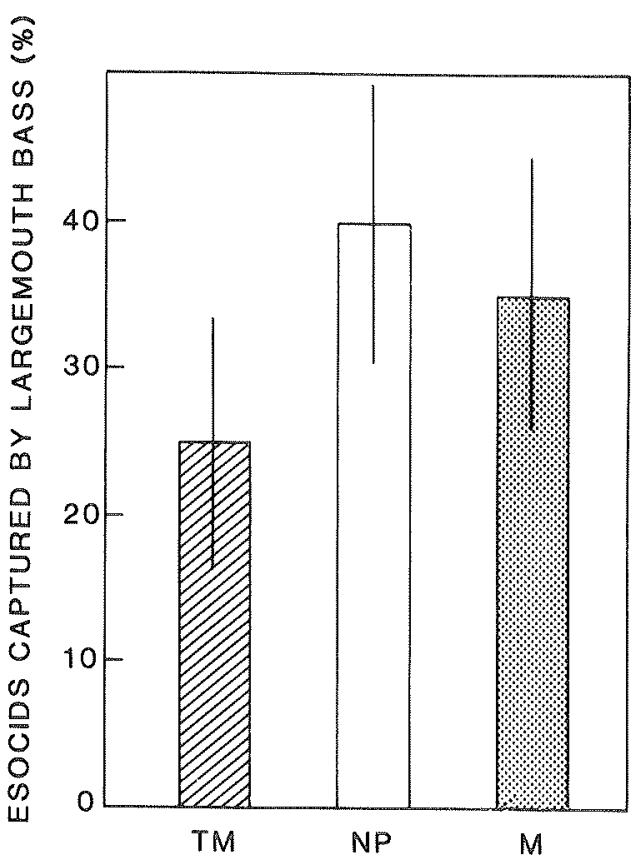

FIG. 6. Percent of each esocid taxon captured by largemouth bass after $24 \mathrm{~h}(N=106$ experiments $)$ in laboratory pools $(2.5 \mathrm{~m}$ in diameter $)$. Vertical lines represent $95 \%$ confidence intervals. No difference in susceptibility to predation was observed among esocid taxa (chisquare, $p=0.15$ ).

mean number of captures for individual largemouth bass also indicated no difference among taxa (Friedman rank sums, $p=$ $0.18)$.

\section{Discussion}

In both pond and reservoir experiments, we found that tiger muskellunge were most susceptible to largemouth bass predation, followed by northern pike and muskellunge. Losses to predation determined by examination of largemouth bass stomachs were confirmed in pond experiments by actual esocid survival. Direct estimates of predation losses were more reliable, as other sources of mortality (handling or other predators, such as birds) were important in at least some ponds. In reservoir experiments, the magnitude of predation mortality determined for tiger muskellunge $(1-53 \%)$ was similar to that observed in previous reservoir studies $(0-45 \%$ ) (Stein et al. 1981; Carline et al. 1986).

Size, presence of alternate prey, and density of largemouth bass may influence predation on tiger muskellunge (Stein et al. 1981; Carline et al. 1986) and muskellunge (Johnson 1982; Serns and Andrews 1986). For all taxa in reservoirs, predatory losses were least for the largest size class stocked. For smaller esocids, the number of largemouth bass in a population capable of ingesting them was higher than for larger esocids. Bassrelated mortality increased as size of tiger muskellunge and northern pike decreased. However, low predatory mortality for muskellunge in one experiment with small esocids (Kokosing Reservoir) and few stockings $(N=5)$ combined to yield no significant relationship with size for this taxon. Size also was important in pond experiments; larger esocids suffered lower predatory mortality.

Availability of alternate forage and predator density did not appear to influence predation mortality in reservoirs. Losses of esocids to predators were unrelated to either percentage of largemouth bass with empty stomachs or density of largemouth bass. In contrast, Carline et al. (1986) found positive correlations for tiger muskellunge, concluding that largemouth bass were most likely to eat recently stocked hybrids when other prey were not abundant and predator densities were high. However, their conclusions were affected strongly by data from Bird's Pond in which largemouth bass were food limited ( $\sim 80 \%$ empty stomachs) and dense ( $\sim 75 / \mathrm{ha})$. If we limit comparisons with Carline et al. (1986) to congruent ranges of predator densities and empty stomachs ( $1-12 /$ ha and $40-60 \%$ empty), then 
predation intensity in both studies becomes unrelated to either predator density or empty stomachs.

To explain differential susceptibility among these esocids, we evaluated taxon-specific habitat selection and movement patterns following stocking. In all systems (reservoirs, hatchery ponds, and laboratory pools), esocids preferred vegetated habitats. Similarly, young-of-year northern pike in the Mississippi River prefer vegetation (Holland and Huston 1984). Tiger muskellunge spent more time in open habitats than the other two taxa. Also, tiger muskellunge and muskellunge spent more time suspended in the water column whereas northern pike were associated with the substrate. These differences in habitat selection may be caused by differences in rearing environment. Because of their experience with pellets dropped from above, tiger muskellunge may reside in open water near the surface following stocking. Differences in habitat use may affect predation risk in esocids as has been observed previously in communities of rodents and sunfishes (Werner et al. 1983; Kotler 1984; Mittelbach 1984). Habitat heterogeneity reduces predation rates by piscivores (Nyberg 1971; Mittelbach 1984; Savino and Stein 1982); prey which remain in the open, such as tiger muskellunge, are more vulnerable to predation.

We also evaluated if differential dispersal could influence susceptibility to largemouth bass. In previous work, predation by largemouth bass correlated strongly with movement of tiger muskellunge (Stein et al. 1981). As hybrids moved through the reservoir and were exposed to a progressively larger fraction of the largemouth bass population, predation mortality increased. Because dispersal rate following stocking did not differ among taxa, this is not a likely explanation for differential mortality.

In contrast with field results, laboratory experiments revealed no difference in susceptibility to predation. Behavior important in determining predation in the laboratory may not be important in the field where predators and prey are not confined by pool walls. Experimental pools were small, allowing largemouth bass to search the entire system frequently. As a result, position changes by esocids in an attempt to avoid predator encounters increased dramatically over those observed in the absence of largemouth bass. In the laboratory, largemouth bass are more likely to attack prey in closer proximity or with greater motion (Howick and O'Brien 1983). Although distances maintained by esocids from largemouth bass did not differ across taxa or habitats, flight distances did vary, being greater for all taxa in open habitats. As a result, largemouth bass followed esocids more frequently in open habitats. Whereas increased motion may attract largemouth bass in pools, it may not be important in the reservoirs and, in fact, may facilitate escape. In fact, failure to flee in the field may allow a searching predator to approach within striking distance. Tiger muskellunge failed to react to an approach by largemouth bass more frequently than either muskellunge or northern pike. Because tiger muskellunge held in hatchery troughs become acclimated to human movements, they may startle less easily than muskellunge and northern pike reared in ponds. Escape and startle responses habituate in fish (Rodgers et al. 1963) and may increase suceptibility of tiger muskellunge to predation.

Esocid behavior provides some insight into mechanisms of differential susceptibility to predation. Movement rates and distance from the predator were similar among the three taxa and flight distance did not vary predictably with vulnerability to predation. In contrast, habitat selection and flight response differed between tiger muskellunge and its parents. Tiger muskellunge spent more time in open habitats and failed to flee more frequently than muskellunge or northern pike. These behavioral differences explain, at least partially, the increased vulnerability of tiger muskellunge to predation.

\section{Management Recommendations}

Behavioral differences among these esocids may be innate or related to differences in rearing environment. Recent efforts to rear northern pike and muskellunge on pelleted diets in hatchery troughs have become increasingly successful ( $S$. Hood, PA Fish. Comm., pers. comm.). Forney and McKeown (1988) documented lower survival for pellet-reared muskellunge than for pond-reared fish, supporting the hypothesis that rearing environment can contribute to success. However, intensively reared muskellunge were stocked earlier in the year and at smaller sizes than pond-reared fish, factors we found critical to survival. Mechanisms of mortality in intensively versus extensively reared esocids must be understood before the contribution of rearing environment to survival can be assessed.

Many factors influence where esocids should be stocked, including presence of appropriate forage (Carline et al. 1986; Wahl and Stein 1988), availability of suitable habitat (Dombeck et al. 1986), as well as density and size structure of resident predators. Managers must decide the time of year, size, and taxon of esocid to stock. We reduced losses to largemouth bass predation by stocking all three esocids in fall when water temperatures were $<25^{\circ} \mathrm{C}$ and when esocid sizes were $>205 \mathrm{~mm}$. From their work with tiger muskellunge, Stein et al. (1981) concluded that $250-\mathrm{mm}$ fish would be relatively free from predation. Tiger muskellunge were more susceptible to predation than northern pike or muskellunge in our experiments, suggesting that stocking sizes for the hybrid should be larger than for the other two species when predators are abundant. Fall stockings will increase survival of esocids for several reasons including dispersal of predators following destratification (Stein et al. 1981), reduced food consumption by largemouth bass at temperatures $<25^{\circ} \mathrm{C}$ (Rice and Cochran 1984), and reduced thermal stress caused by differences in temperatures between hatchery and lake (Mather and Wahl 1989).

\section{Acknowledgements}

We thank Tim Nagel (London Fish Farm) and Pat Keyes (Hebron Fish Farm) for providing esocids and D. B. Apgear and C. Lakes for coordinating activities with the Ohio Division of Wildlife. Many individuals associated with the Aquatic Ecology Laboratory provided volunteer and technical assistance; in particular the efforts of D. Bryson, K. Bruner, D. Imhoff, L. Riley, J. Farwick, J. Bohne, P. Cunningham, A. Turner, F. Rahel, M. Mather, J. Wahl, and C. Habicht were critical to this research effort. Data analyses were facilitated by the Statistical Consulting Service, Department of Statistics, The Ohio State University. L. Einfalt drafted the figures. F. J. Margraf, G. G. Mittelbach, J. Bart, and L. B. Crowder critically reviewed the manuscript. This study was supported in part by funds from the Federal Aid in Fish Restoration Act under Project F-57-R.

\section{References}

BEAMISH, F. W. H. 1972. Ration size and digestion in largemouth bass, Micropterus salmoides Lacepede. Can. J. Zool. 50: 153-164.

Belusz, L. C. 1978. An evaluation of the muskellunge fishery of Lake Pomme de Terre and efforts to improve stocking success. Am. Fish. Soc. Spec. Publ. 11: 292-297.

CARline, R. F, R. A. STEIN, AND L. M. Riley. 1986. Effects of size at stocking, season, largemouth bass predation, and forage abundance on survival of tiger muskellunge. Am. Fish. Soc. Spec. Publ. 15: 151-167. 
Crossman, E. J., AND J. M. CASSELMAN. 1969. Identification of nor them pike and muskellunge from axial skeletons, scales, and epipleurals. J. Fish. Res. Board Can. 26: 175-178

Crowder, L. B., AND W. E. COOPER. 1982. Habitat structural complexity and the interaction between bluegills and their prey. Ecology 63: 1802-1813.

Dombeck, M. P., B. W. MENZEL, AND P. N. Hinz. 1986. Natural muskellunge reproduction in midwestern lakes. Am. Fish. Soc. Spec. Publ, 15: 122-134.

Forney, J. L., AND P. E. MCKEOwN. 1988. Status of fish stocks in Chautauqua Lake 1987. New York Deparment of Environmental Conservation, Federal Aid in Fish Restoration Project 7, Albany, NY.

FOSTER, J. R. 1977. Pulsed gastric lavage: an efficient method of removing the stomach contents of live fish. Prog. Fish-Cult. 39: 166-169.

GRAFF, D. R. 1978. Intensive culture of esocids: the current state of the art. Am. Fish. Soc. Spec. Publ. 11: 195-201

HEADRICK, M. R. 1985. Bioenergetic constraints on habitat use by northern pike (Esox lucius) in Ohio reservoirs. Doctoral dissertation, The Ohio State University, Columbus, OH.

HOLLAND, L. E., AND M. L. HUSTON. 1984. Relationship of young-of-the-year northern pike to aquatic vegetation types in backwaters of the Upper Mississippi River. N. Am. J. Fish. Manage. 4: 514-522.

HowICK, G. L., AND W. J. O'BRIEN. 1983. Piscivorous feeding behavior of largemouth bass: an experimental analysis. Trans. Am. Fish. Soc. 112: $508-516$.

HuNT, B. P. 1960. Digestion rate and food consumption of Florida gar, warmouth and largemouth bass. Trans. Am. Fish. Soc. 89: 206-211.

Hurlbert, S. H., J. ZedLer, AND D. FairbanKS. 1972. Ecosystem alteration by mosquito fish (Gambusia affinis) predation. Science (Wash., DC) 175: $639-641$.

JOHNSON, L. D. 1978. Evaluation of esocid stocking program in Wisconsin. Am. Fish. Soc. Spec. Publ. 11: 298-301.

1982. Factors affecting short-term survival of stocked muskellunge fingerlings in Wisconsin. Wisconsin Department of Natural Resources, Federal Aid in Fish Restoration Project F-83, Madison, WL.

KoTLER, B. P. 1984. Risk of predation and the structure of desert rodent communities. Ecology 65: 689-701

MACAN, T. T. 1977. The influence of predation on the composition of freshwater animal communities. Biol. Rev. 52: 45-70.
MATHER, M. E., AND D. H. WAHL. 1989. Comparative mortality in three esocids due to stocking stress. Can. J. Fish. Aquat. Sci, 46:214-217.

MitTelbach, G. G. 1984. Predation and resource partitioning in two sunfishes (Centrarchidae). Ecology 65: 499-513.

MORIN, P. J. 1984. The impact of fish exclusion on the abundance and species composition of larval odonates: the results of short-term experiments in a North Carolina farm pond. Ecology 65: 53-60.

NYBERG, D. W. 1971. Prey capture in the largemouth bass. Am. Midl. Nat. 86: $128-144$.

PECKARSKY, B. L., AND S. I. DODSON. 1980. Do stonefly predators influence benthic distributions in streams? Ecology $61: 1275-1282$.

RiCE, J. A., AND P. A. CoChraN. 1984. Independent evaluation of a bioenergetics model for largemouth bass. Ecology 65: 732--739.

RICKER, W. E. 1985. Computation and interpretation of biological statistics of fish populations. Bull. Fish. Res. Board Can. 191.

Rodgers, W. L., R. MELZACK, AND J. R. SEGAL. 1963. 'Tail flip response' in goldfish. J. Comp. Physiol. Psychol, 56: 917-923.

SAvino, J. F. AND R. A. STEIN, 1982. Predator-prey interaction between large mouth bass and bluegills as influenced by simulated, submerged vegeta. tion. Trans. Am. Fish. Soc. 111: 255-266.

Serns, S. L., AND L. M. Andrews. 1986. Comparative survival and growth of three sizes of muskellunge fingerlings stocked in four northern Wisconsin lakes. Am. Fish. Soc. Spec. Publ. 15: 229-237.

Steel, R. D., AND J. H. Torrie. 1980. Principles and procedures of statistics: a biometrical approach. McGraw Hill, New York, NY.

Stein, R. A., R. F. Carline, And R. S. Hayward. 1981. Largemouth bass predation on stocked tiger muskellunge. Trans. Am. Fish. Soc. 110: 604 612.

WAHL, D. H., AND R. A. STEIN. 1987. Application of liquid oxytetracycline in formulated feeds to mark and treat tiger muskellunge (northern pike $X$ muskellunge). Prog. Fish-Cult. 49: 312-314.

1988. Prey selection by three esocids: the role of prey behavior and morphology. Trans. Am. Fish. Soc. 117: 142-151.

WEITHMAN, A.S., AND R. O. ANDERSON. 1977. Survival, growth, and prey of Esocidae in experimental systems. Trans. Am. Fish. Soc. 106:424-430.

Werner, E. E., J. F. Gilliam, D. J. Hall, AND G. G. MitTel bach. 1983. An experimental test of the effects of predation risk on habitat use in fish. Ecology 64: 1540-1548. 